\title{
Pengetahuan Ibu dan Dukungan Suami berhubungan dengan Pemakaian Metode Kontrasepsi Jangka Panjang (MKJP)
}

\author{
Safitri \\ Program Studi DIII Kebidanan STIKes Baiturrahim Jambi \\ Email: safitrypipit@gmail.com
}

Submitted : 23/07/2020

Accepted: 11/01/2021

Published: 06/03/2021

\begin{abstract}
The public health center Pakuan Baru Jambi cityis the public health center with the lowerst uses a method of long-term contraception.The low use of long-term contraceptive methods can be caused by ignorance about the advantages of the MKJP and the obstacle of supporthusband in using the method. This study is a quantitative study, with a cross sectional design that aims todeterminethe relationship between mother'sknowledge and supporthusband to the use of MKJPin the public health center Pakuan Baru, Jambi city. Data collection on mother'sknowledge and supporthusband using a questionnaire.As many as 42 study subjects were selected by simple random sampling. This study was analyzed using the chi square statistical test.The results of the study there is a relationship between mother'sknowledge and support husband to the use of MKJP, with mother'sknowledge $p$ value $=0.036$ and support husband $p$ value $=0,000$. The results of this study can be used as a rationale for policymaking in order to increase the number of long-term family planning acceptors.
\end{abstract} Keywords: mother'sknowledge, support the husband, MKJP

\begin{abstract}
Abstrak
Puskesmas Pakuan Baru Kota Jambi merupakan Puskesmas yang mempunyai cakupan pengguna Metode Kontrasepsi Jangka Panjang (MKJP)terendah.Rendahnya penggunaan metode kontrasepsi jangka panjang dapat disebabkan karenaketidaktahuan tentang kelebihanMKJP dan adanya hambatan dukungan dari suami dalam pemakaian metode tersebut. Penelitian ini merupakan penelitian kuantitatif, dengan desain cross sectional yang bertujuan untuk mengetahui hubungan pengetahuan ibu dan dukungan suami terhadap pemakaian MKJP di Puskesmas Pakuan Baru Kota Jambi. Pengumpulan data pengetahuan ibu dan dukungan suami menggunakan kuesioner. Subjek penelitian sebanyak 42 dipilih secarasimple random sampling. Penelitian ini dianalisis dengan menggunakan uji statistik chi square. Hasil penelitian ada hubungan antara pengetahuan ibu dan dukungan suami dengan pemakaian MKJP, dengan nilai $p$ value pengetahuan ibu $=0,036$ dan dukungan suami $p$ value $=0,000$. Hasil penelitian ini dapat dijadikan dasar pemikiran dalam pembuatan kebijakan dalam rangka meningkatkan jumlah akseptor KB jangka panjang.
\end{abstract}

Kata Kunci: pengetahuan ibu, dukungan suami, MKJP

\section{PENDAHULUAN}

Masalah utama kependudukan di Indonesia yaitu pertumbuhan penduduk yang tinggi. Jumlah penduduk Indonesia berdasarkan hasil estimasi pada tahun 2018 sebesar 265.015.313 jiwa, terdiri atas 133.136.131 jiwa penduduk laki-laki dan 131.879.182 jiwa penduduk perempuan (Kemenkes RI, 2019).

Laju pertumbuhan penduduk pada periode 2015-2020 sebesar 1,06 persen. Angka ini mengalami penurunan dibandingkan pada periode 2010-2015 sebesar 1,38 persen. Angka tersebut tidak menutup kemungkinan akan mengalami kenaikan pada tahun mendatang, maka diperlukan suatu program untuk mempertahankan dan menurunkan pertumbuhan penduduk (BPS, 2018).

Program Keluarga Berencana (KB) merupakan salah satu kebijakan pemerintah dalam upaya pengendalian pertumbuhan penduduk dengan menurunkan jumlah kelahiran. Menurut World Health Organization(WHO), KB adalah tindakan yang membantu individu atau pasangan suami istri untuk mendapatkan objektif tertentu, 
menghindari kelahiran yang tidak diinginkan, mengatur interval di antara kehamilan, mengontrol waktu saat kelahiran dalam hubungan suami istri dan menentukan jumlah anak dalam keluarga. Program KB bertujuan untuk menurunkan angka kelahiran, menurunkan Angka Kematian Ibu (AKI) dan Angka Kematian Bayi (AKB) sehingga terwujud keluarga yang sehat dan berkualitas (BKKBN, 2016).

Angka Total Fertility Rate(TFR) Indonesia periode 2015-2010 tertinggi keenam di negara Asia yaitu sebesar 2,1 per wanita subur, proyeksi terendah diduduki negara Singapura yaitu sebesar 1,26 per wanita subur (BPS, 2018). Tingginya angka TFR di Indonesia disebabkan oleh berbagai faktor, salah satunya adalah program KB yang belum berjalan secara optimal. Berbagai strategi telah dilakukan untuk mengoptimalkan program KB. Strategi pelaksanaan program KB yang tercantum dalam Rencana Pembangunan Jangka Menengah (RPJMN) 2015-2019 adalah meningkatkan penggunaan MKJP (Kemenkes RI, 2019).

MKJP merupakan salah satu program pemerintah namun angka pencapaian akseptor MKJP masih tergolong rendah dibandingkan metode yang lain. Rendahnya penggunaan metode kontrasepsi jangka panjang dapat disebabkan karena beberapa faktor seperti: ketidaktahuan peserta tentang kelebihan metode kontrasepsi jangka panjang, kualitas pelayanan KB dilihat dari segi ketersediaan alat kontrasepsi dan ketersediaan tenaga yang terlatih serta kemampuan medis teknis petugas pelayanan kesehatan, biaya pelayanan metode kontrasepsi jangka panajang yang mahal, adanya hambatan dukungan dari suami dalam pemakaian metode kontrasepsi jangka panjang, dan adanya nilai yang timbul dari adanya persepsi atau keyakinan yang didasarkan kepercayaan dan norma-norma dimasyarakat(Nurcahyanti, 2014).

Dukungan suami dapat memengaruhi penggunaan kontrasepsi pada istri. Rendahnya penggunaan metode kontrasepsi dikarenakan suami menolak menggunakan $\mathrm{KB}$ dan terbatasnya kekuatan istri dalam pengambilan keputusan untuk menggunakan KB. Untuk memilih kontrasepsi yang akan digunakan, seorang istri tentunya harus berkomunikasi dengan pasangannya, membutuhkan pendapat dan dukungan dari pasangannya. Kurangnya dukungan suami yang diberikan akan mempengaruhi kepercayaan diri istri untuk memilih kontrasepsi yang ingin digunakan (Prata, 2017).

Berdasarkan Badan Kependudukan dan Keluarga Berencana Nasional (BKKBN), KB aktif di antara PUS tahun 2018 sebesar 63,27\%, hampir sama dengan tahun sebelumnya yang sebesar 63,22\%. Sementara target RPJMNyang ingin dicapai tahun 2019 sebesar 66\%. Dari keseluruhan jumlah peserta KB modern, hanya $17,8 \%$ diantaranya yang menggunakan KB MKJP. Sedangkan 82,19\% lainnya pengguna KB non MKJP. Metode kontrasepsi yang paling banyak digunakan oleh peserta KB aktif adalah suntik $(63,71 \%)$ dan terbanyak kedua adalah pil $(17,24 \%)$, selanjutnya IUD $(7,35 \%)$, implan $(7,2 \%)$, MOW $(2,76 \%)$, kondom $(1,24 \%)$, dan MOP $(0,5 \%)$ (Kemenkes, 2019).

Jumlah peserta KB aktif dari 20 Puskesmas di Kota Jambi tahun 2017 sebanyak 95.535 orang. Terdiri dari pengguna metode kontrasepsi suntik sebanyak 37.746, pil sebanyak 14.557, kondom sebanyak 2.120, IUD sebanyak 2.032, implan sebanyak 1.252, MOW sebanyak 542, dan MOP sebanyak 16. Berdasarkan data tersebut, Puskesmas Pakuan Baru merupakan Puskesmas yang mempunyai cakupan pengguna MKJP terendah terdiri dari implant $(0,3 \%)$ dan 
IUD, MOW, MOP (0\%). Peserta KB aktif di Puskemas Pakuan Baru sebanyak 4.465 (Dinkes Kota Jambi, 2018).

Berdasarkan survey awal yang telah dilakukan, penggunaan MKJP yang sedikit dikarenakan masyarakat masih beranggapan bahwa MKJP adalah metode kontrasepsi yang digunakan untuk mengakhiri mempunyai anak dan adanya rasa takut pada saat pemasangan IUD melalui jalan lahir serta ketidaknyamanan saat berhubungan, sehingga banyak akreptor yang lebih memilih menggunakan Non MKJP. Masyarakat hanya mengenal jenis-jenis MKJP tanpa tau kelebihan atau keuntungan serta efek samping dari MKJP. Sebagian besar akseptor tidak didampingi oleh suami saat pemakaian kontrasepsi, hal ini dikarenakan suami memiliki kesibukan untuk mencari nafkah ketika jadwal kunjungan ulang atau kontrol ulang.

Berdasarkan latar belakang di atas penulis tertarik untuk melakukan penelitian dengan judul "Hubungan Pengetahuan Ibu dan Dukungan Suami terhadap Pemakaian Metode Kontrasepsi Jangka Panjang (MKJP) di Puskesmas Pakuan Baru Kota Jambi”.

\section{METODE PENELITIAN}

Penelitian ini merupakan penelitian kuantitatif, dengan pendekatan cross sectional. Pengumpulan data pengetahuan ibu dan dukungan suami menggunakan kuesioner. Penelitian dilakukan diPuskesmas Pakuan Baru Kota Jambi. Penelitian dilaksanakan pada bulan Januari-Maret tahun 2020. Populasi penelitian ini adalah seluruh akseptor KB aktif yang berada di Puskesmas Pakuan Baru pada bulan Januari-Maret tahun 2019 berjumlah 724 orang. Sampel pada penelitian ini berjumlah 42 orang yang dipilih secara simple random samplingsesuai dengan kriteria inklusi yaituakseptor KB aktif yang mendapatkan pelayanan dan berdomisili di wilayah kerja Puskesmaas Pakuan Baru dan akseptor KB yang bersedia menjadi responden. Sedangkan kriteria eksklusi yaitu akseptor KB yang sedang sakit dan akseptor KB yang tidak bisa membaca dan menulis.

\section{HASIL DAN PEMBAHASAN}

Hasil penelitian menunjukkan bahwa sebagian besar $(74 \%)$ responden berada pada rentang umur 20-35 tahun, sebagian besar (66\%) pendidikan responden berada pada rentang menengah (SLTA), sebagian besar $(88 \%)$ pekerjaan responden adalah IRT dan sebagian $(57 \%)$ responden memiliki anak kurang dari 2 orang (Tabel 1).

\section{Tabel 1.Karakteristik}

\begin{tabular}{lcc}
\hline Karakteristik & F & \% \\
\hline Umur & 31 & 74 \\
20-35 tahun & 11 & 26 \\
$>35$ tahun & & \\
Pendidikan & 7 & 17 \\
Dasar (SD, SMP) & 28 & 66 \\
Menengah (SMA) & 7 & 17 \\
Tinggi (PT) & & \\
Pekerjaan & 37 & 88 \\
IRT & 2 & 5 \\
Swasta & 2 & 5 \\
Guru & 1 & 2 \\
PNS & & \\
Jumlah Anak & 24 & 57 \\
$\leq 2$ & 18 & 43 \\
\hline 2 & 42 & 100 \\
\hline Total & & \\
\hline
\end{tabular}


Hasil penelitian menunjukkan bahwa jenis kontrasepsi yang paling dominan pada akseptor KB adalah penggunaan non-MKJP (60\%), sebagian besar (76\%) responden memiliki pengetahuan baik tentang MKJP dan sebagian (57\%) responden mendapat dukungan suami dalam menggunakan MKJP (Tabel 2).

\section{Tabel2. Analisis Univariat}

\begin{tabular}{lcc}
\hline Variabel & F & \% \\
\hline Metode Kontrasepsi & & 60 \\
MKJP & 25 & 40 \\
Non-MKJP & 17 & 76 \\
Pengetahuan Ibu & & 24 \\
Baik & 32 & 57 \\
Kurang Baik & 10 & 43 \\
Dukungan Suami & & 100 \\
Mendukung & 24 & \\
Tidak Mendukung & 18 & \\
\hline Total & 42 & \\
\hline
\end{tabular}

Pada analisis bivariat ditemukan adanya hubungan antara pengetahuan ibu dan dukungan suami dengan pemakaian MKJP, dengan nilai $p$ value pengetahuan ibu $=0,036$ dan dukungan suami $p$ value $=$ 0,000.Dari 32 responden yang memiliki pengetahuan baik, sebagian besar (69\%) menggunakan MKJP dan dari 10 responden yang memiliki pengetahuan kurang baik, sebagian besar $(70 \%)$ tidak menggunakan MKJP. Sedangkan dari 24 responden yang mendapat dukungan suami, sebagian besar (92\%) menggunakan MKJP dan dari 18 responden yang tidak mendapat dukungan suami, sebagian besar $(83 \%)$ tidak menggunakan MKJP(Tabel 3).

Tabel3. Analisis Bivariat

\begin{tabular}{|c|c|c|c|c|c|c|c|}
\hline \multirow{3}{*}{ Variabel } & \multicolumn{4}{|c|}{ Metode Kontrasepsi } & \multirow{2}{*}{\multicolumn{2}{|c|}{ Total }} & \multirow{3}{*}{$P$ value } \\
\hline & \multicolumn{2}{|c|}{ MKJP } & \multicolumn{2}{|c|}{ Non-MKJP } & & & \\
\hline & $\mathbf{N}$ & $\%$ & $\mathbf{N}$ & $\%$ & $\mathbf{N}$ & $\%$ & \\
\hline Pengetahuan & & & & & & & \multirow{4}{*}{0,036} \\
\hline Baik & 22 & 88 & 10 & 59 & 32 & 76,2 & \\
\hline Kurang Baik & 3 & 12 & 7 & 41 & 10 & 23,8 & \\
\hline \multicolumn{7}{|l|}{ Dukungan Suami } & \\
\hline Mendukung & 22 & 88 & 2 & 12 & 24 & 57,2 & \multirow{2}{*}{0,000} \\
\hline Tidak Mendukung & 3 & 12 & 15 & 88 & 18 & 42,8 & \\
\hline Total & 25 & 100 & 17 & 100 & 42 & 100 & \\
\hline
\end{tabular}

Berdasarkan hasil penelitian di Puskesmas Pakuan Baru Kota Jambi menunjukkan sebagian besar (60\%) responden menggunakan MKJP, pemakaian MKJP terbanyak yaitu 52\% kontrasepsi IUD. Hasil ini didukung oleh penelitian Triyanto dkk (2018) dengan judul "Faktor yang Mempengaruhi Penggunaan Jenis Metode Kontrasepsi Jangka Panjang (MKJP) pada Wanita Menikah Usia Subur di Provinsi Jawa
Timur" menunjukkan bahwa MKJP terbanyak yang digunakan oleh WUS di Provinsi Jawa Timur adalah metode IUD sebesar 42,7\%, kemudian diikuti MOW $30,4 \%$ dan implan $26,9 \%$.

Metode IUD ini adalah metode kontrasepsi yang cukup efektif, tahan lama (hingga 10 tahun proteksi), efisien, nyaman dan biaya yang dikeluarkan relatif murah. Tingkat kegagalan pada setahun pertama sangat rendah mencapai 
angka $0,8 \%$. Keuntungan lainnya adalah penggunaan MKJP ini tidak bergantung pada kalender haid ataupun kepatuhan dalam meminum pil atau kunjungan ke dokter.Metode IUD merupakan metode kontrasepsi yang baik, karena aman, tidak mempengaruhi kesuburan bahkan setelah melepaskannya, fleksibel menyesuaikan dengan bentuk rahim dan mudah dilepas, dan sangat efektif (Turangan, 2016).

Menurut sebagian besar responden, menggunakan kontrasepsi IUD merupakan alat kontrasepsi yang aman dan tergolong manjur dalam mencegah terjadinya kehamilan. Mereka juga beranggapan bahwa kontrasepsi IUD lebih murah dan aman dibandingkan dengan kontrasepsi jenis MOW, serta meningkatkan kenyamanan seksual karena tidak perlu takut untuk hamil. Penggunaan MKJP dengan metode IUD juga tidak memiliki pengaruh terhadap lingkungan seksual, tidak ada pengaruh terhadap hormon, apabila masih program menyusui juga tidak akan mengganggu produksi ASI setelah dipasang segera setelah melahirkan.

Hasil dari analisis uji statistik didapatkan nilai $\mathrm{p}$ value $=0,036$, hal ini menunjukkan ada hubungan yang signifikan antara pengetahuan ibu dengan pemakaianMKJPdi Puskesmas Pakuan Baru Kota Jambi.

Hasil penelitian ini sejalan dengan penelitian yang dilakukan oleh Widyarni dkk (2018) dengan judul "Hubungan Pengetahuan dan Sikap Ibu terhadap Penggunaan KB Metode Kontrasepsi Jangka Panjang (MKJP) di Wilayah Kerja Puskesmas Pasaman Kabupaten Banjar, Martapura" yang menyatakan bahwa adanya hubungan yang signifikan antara pengetahuan responden dengan penggunaan MKJP dengan $\mathrm{p}$ value $=$ 0,001 . Pendapat ini diperkuat lagi dalam penelitian yang dilakukan oleh Setiasih dkk (2016) dengan judul "Analisis Faktor-Faktor yang Mempengaruhi Pemilihan Metode Kontrasepsi Jangka
Panjang (MKJP) pada Wanita Pasangan Usia Subur (PUS) di Kabupaten Kendal Tahun 2013" juga menyatakan bahwa adanya hubungan antara pengetahuan responden dengan pemilihan MKJP dengan $\mathrm{p}$ value $=0,034$.

Pengetahuan dapat membentuk keyakinan tertentu sehingga seorang berprilaku sesuai dengan keyakinan tersebut. Pengetahuan atau kognitif merupakan domain yang sangat penting untuk terbentuknya tindakan seseorang dan merupakan faktor predisposisi terbentuknya perilaku termasuk perilaku penggunaan MKJP. Pengetahuan berpengaruh dalam proses pengambilan keputusan untuk menerima suatu inovasi. Pengetahuan yang tinggi dapat menggambarkan wawasan yang lebih luas sehingga memudahkan dalam menerima inovasi baru dan pengambilan keputusan yang sesuai. Tingkat pengetahuan seseorang yang tinggi, selain dikarenakan tingkat pendidikan yang tinggi, juga dipengaruhi oleh keaktifan seseorang dalam mencari informasi. Pengetahuan seseorang dapat diperoleh dari keikutsertaan dalam kegiatan, misalnya penyuluhan alat kontrasepsi (Setiasih dkk, 2016).

Pada penelitian ini pengetahuan akseptor dalam kategori sebagian besar $(76 \%)$ baik dengan sebagian besar $(66 \%)$ pendidikan berada pada rentang menengah (SMA), sehingga informasi yang diperoleh sudah cukup banyak tentang MKJP. Pengetahuan akseptor KB yang baik tentang hakekat program $\mathrm{KB}$ akan mempengaruhi mereka dalam memilih metode kontrasepsi yang akan digunakan termasuk keleluasaan atau kebebasan pilihan, kecocokan, pilihan efektif tidaknya, kenyamanan dan keamanan, juga dalam memilih tempat pelayanan yang lebih sesuai karena wawasan sudah lebih baik, sehingga kesadaran mereka tinggi untuk memanfaatkan pelayanan.

Pengetahuan seseorang berpengaruh dalam proses pengambilan keputusan 
untuk menerima sesuatu hal yang baru. Ibu yang memiliki pengetahuan baik maka akan memiliki tingkat kepercayaan untuk menggunakan MKJP. Tetapi adapun ibu yang berpengetahuan baik banyak yang tidak menggunakan MKJP hal itu dikarenakan mereka mengetahui efeknya serta cara pemasangannya padahal efek yang ditimbulkan hanya untuk penyesuaian tetapi mereka takut selain itu suami mendukung, dana tersedia tapi mereka lebih memilih menggunakan Non MKJP alasannya lebih simpel hanya minum pil dan suntik. Sedangkan ibu-ibu yang berpengetahuan kurang baik ada yang menggunakan MKJP karena adanya bantuan gratis dari pemerintah melalui kegiatan safari KB tanpa mereka tau lebih jelas bagaimana cara kerja serta efeknya dan alasan yang diberikan kebanyakan lebih baik menggunakan MKJP dari pada harus mengeluarkan dana setiap bulannya serta bisa membatasi jumlah anak karena ekonomi yang terbatas. Direkomendasikan ibu-ibu mendapatkan informasi kesehatan tentang MKJP lebih jelas dari petugas kesehatan.

Ada hubungan yang signifikan antara dukungan suami dengan pemakaian MKJP di Puskesmas Pakuan Baru Kota Jambi pada Tahun 2020 dengan p-value $=0,000$.

Hasil penelitian ini didukung dengan penelitian yang dilakukan oleh Ningrum dkk (2018) dengan judul "Faktor-Faktor yang Berhubungan dengan Pemilihan Metode Kontrasepsi Jangka Panjang (MKJP) pada Pasangan Usia Subur di Wilayah Kerja Puskesmas Batang Hari Kabupaten Lampung Timur" yang menyatakan bahwa terdapat hubungan yang bermakna antara dukungan suami dengan pemilihan kontrasepsi MKJP dengan $\mathrm{p}$ value $=0,037$. Penelitian serupa oleh Nurlisis dkk (2016) menunjukkan ada hubungan yang signifikan antara dukungan suami dengan pemakaian metode kontrasepsi jangka panjang di Wilayah Kerja Puskesmas Rumbai Pesisir tahun 2014 dengan p value $=0,001$.

Dukungan suami terhadap istri dalam berKB merupakan partisipasi suami secara tidak langsung dalam berKB dengan menganjurkan, mendukung dan memberi kebebasan kepada istri untuk menggunakan kontrasepsi diawali sejak pria melakukan akad nikah dengan pasangannya, dalam merencanakan jumlah anak yang akan dimiliki sampai dengan akhir masa menopause istrinya (BKKBN, 2016).

Pada penelitian ini dukungan suami pada akseptor sebagian besar (57\%) mendukung. Dukungan suami terhadap istri dalam memilih alat kontrasepsi merupakan hal yang sangat penting, karena akseptor harus mendapatkan kenyamanan dalam menggunakan kontrasepsi hal tersebut bisa didapatkan dari dukungan keluarga terutama suami karena suami merupakan pemegang kekuasaan dalam pengambilan keputusan apakah istri akan menggunakan kontrasepsi atau tidak. Tidak adanya dukungan suami disebabkan karna beberapa faktor diantaranya pengetahuan yang kurang, pendidikan, kurangnya partisipasi suami dalam ber KB, tidak mau mengantarkan istri ke tempat pelayanan, tidak ada dana yang diberikan, namun sebagian dari suami responden ada yang berpengetahuan rendah tetapi mereka ikut berpatisipasi dalam ber $\mathrm{KB}$, mendukung adanya program gratis dari pemerintah yang bermanfaat untuk mengatur jumlah anak.

Idealnya pasangan akan mendiskusikan, mempertimbangkan untuk memilih metode kontrasepsi terbaik secara bersama, bekerjasama satu sama lain dalam penggunaan kontrasepsi dan memperhatikan efek samping kontrasepsi tersebut. Jika informasi tentang MKJP hanya diketahui oleh istri sementara suami kurang konseling dan informasi, suami kadang-kadang melarang istri mereka untuk menggunakan MKJP karena faktor ketidaktahuan dan tidak ada 
komunikasi untuk saling memberikan pengetahuan. Pengambilan keputusan dan komunikasi yang baik dalam pemilihan kontrasepsi bukanlah hal yang mudah. Seorang istri dalam mengambil keputusan untuk menggunakan atau tidak kontrasepsi diperlukan persetujuan dari suaminya karena suaminya dipandang sebagai kepala keluarga, pelindung keluarga, pencari nafkah dan seseorang yang bisa membuat keputusan dalam keluarga. Pengetahuan yang baik tentang alat kontrasepsi dapat memotivasi suami dan mendorong istrinya untuk menggunakan alat kontrasepsi. Alat kontrasepsi tidak bisa digunakan oleh istri tanpa kerja sama dengan suaminya dan saling percaya (Nur, 2019).

\section{SIMPULAN}

Ada hubungan antara pengetahuan ibu dan dukungan suami dengan pemakaian MKJP.Hasil penelitian ini dapat digunakan sebagai dasar pemikiran pembuatan kebijakan dalam rangka peningkatan jumlah akseptor KB jangka panjang. Selain itu, dapat juga dijadikan sebagai dasar penelitian serupa dengan menggunakan desain penelitian kualitatif yang menggali lebih dalam tentang variabel dukungan suami.

\section{SARAN}

Hasil penelitian ini dapat dijadikan dasar pemikiran dalam pembuatan kebijakan dalam rangka meningkatkan jumlah akseptor KB jangka panjang

\section{DAFTAR PUSTAKA}

BKKBN. 2016. Buku Panduan Praktis Pelayanan Kontrasepsi. Jakarta: Yayasan Bina Pustaka Sarwono Prawirohardjo.

Badan Pusat Statistik, Bappenas, UNFPA. 2018. Proyeksi Penduduk Indonesia 2015-2045. Badan Pusat Statistik, Jakarta.

Dinas Kesehatan Kota Jambi. 2017. Cakupan Pelayanan Keluarga
Berencana Kota Jambi Tahun 2017. Dinas Kesehatan Kota Jambi.

Kementerian Kesehatan RI. 2019. Profil

Kesehatan Indonesia 2018.

Kesehatan Kementerian Kesehatan RI. Jakarta.

Ningrum DAW, Easter D, Sugihati. Faktor-Faktor yang Berhubungan dengan Pemilihan Metode Kontrasepsi Jangka Panjang (MKJP) pada Pasangan Usia Subur di Wilayah Kerja Puskesmas Batang Hari Kabupaten Lampung Timur. J Dunia Kesmas. 2019;7(4):196-203.

Nurcahyanti I. Hubungan Dukungan Suami dalam Pemilihan Metode Kontrasepsi Jangka Panjang pada Ibu Akseptor Kb Berusia Lebih Dari 35 Tahun di Desa Sidomukti Kecamatan Bandungan Kabupaten Semarang. E-Journal NWU. 2014;2(1):71-84.

Nurlisis, Anggraini W. Hubungan Pengetahuan Ibu dan Dukungan Suami dengan Pemakaian Kontrasepsi Jangka panjang di Wilayah Kerja Puskesmas Rumbai Pesisir. J Photon. 2016;6(2):75-80.

Nur R, Bonda R, Rahman A, Hartini DA, Aiman U, Herman, dkk. Determinant Use of Long-Term Contraceptive Methods in Sangurara Community Health Center Area Palu City. CMRO. 2019;6(2):174-9.

Setiasih S, Widjanarko B, Istiarti $\mathrm{T}$. Analisis Faktor-faktor yang Mempengaruhi Pemilihan Metode Kontrasepsi Jangka Panjang (MKIP) pada Wanita Pasangan Usia Subur (PUS) di Kabupaten Kendal Tahun 2013. JPKI 2016;11(2):1-7.

Prata N, Bell S, Fraser A, Carvalho A, Neves I, Nieto-Andrade B. Partner Support for Family Planning and Modern Contraceptive Use in Luanda, Angola. Afr J Reprod Health. 2017;21(2):35-48.

Triyanto, L dan Indriani, D. 2018. Faktor yang Mempengaruhi Penggunaan 
Jurnal Akademka Baiturrahim Jambi (JABJ)Vol 10, No 1, Maret 2021

DOI: 10.36565/jab.v10i1.269

p-ISSN: 2655-9266

e-ISSN: 2655-9218

Jenis Metode Kontrasepsi Jangka Panjang (MKJP) pada Wanita Menikah Usia Subur di Provinsi Jawa Timur. IJPH. 2018;13(2):24455.

Turangan, L. 2016. 7 Alasan Memilih Kontrasepsi IUD. Jakarta.
Widyarni A, Dhewi S. Relationship Of Women's Knowledge And Attitudes To Use Of Kb Long-Term Contraception (MKJP) Method In Working Areas Puskesmas Paramasan Kabupaten Banjar, Martapura. JMR. 2018;2(1):1-7 